\title{
Literasi dalam Pendidikan Anak Usia Dini: Persepsi dan Praktik Guru di Prasekolah Aceh
}

\author{
Mutia Afnida ${ }^{\varpi_{1}}$, Suparno $^{2}$ \\ Pendidikan Anak Usia Dini, Universitas Negeri Yogyakarta ${ }^{1}$ \\ Pendidikan Luar Biasa, Unversitas Negeri Yogyakarta² \\ DOI: $\underline{10.31004 / \text { obsesi.v4i2.480 }}$
}

\begin{abstract}
Abstrak
Penelitian ini dilakukan untuk mengetahui pemahaman dan praktik literasi di dalam pendidikan anak usia dini. Penelitian ini merupakan mixed-method melalui wawancara dan pengisian kuisioner. Hasil data kualitatif dianalisis melalui tahapan reduksi, sajian data, dan penarikan kesimpulan sedangkan data kuantitatif menggunakan analisis deskriptif. Berdasarkan hasil yang diperoleh, literasi dimaknai dengan stimulasi perkembangan kemampuan bahasa anak yang menekankan pada pengetahuan huruf dan kesadaran fonologi, diantaranya: mengajak anak membaca buku, mengenal kosakata melalui kartu bergambar, menirukan bentuk tulisan dan kosakata, serta kegiatan lainnya yang berhubungan dengan baca-tulis anak. Literasi dapat terlaksana dengan baik berdasarkan pengalaman dan pengetahuan serta ketersediaan waktu yang dimanfaatkan. Banyaknya pengetahuan guru tentang literasi akan berdampak pada keragaman kegiatan yang dirancang dan berguna untuk stimulasi perkembangan kemampuan bahasa anak sejak dini. Dengan demikian pengetahuan guru tentang literasi sangat diperlukan, agar isu pro dan kontra tentang baca-tulis untuk anak usia dini dapat dilakukan dengan kegiatan literasi yang sesuai dengan usia anak.
\end{abstract}

Kata Kunci: literasi; persepsi guru; praktik guru; prasekolah

\begin{abstract}
This research was conducted to determine the understanding and practice of literacy in early childhood education. This research is a mixed-method through interviews and questionnaires. The results of qualitative data were analyzed through the stages of reduction, data presentation, and conclusion drawing while quantitative data used descriptive analysis. Based on the results obtained, literacy is interpreted by stimulating the development of children's language skills that emphasize letter knowledge and phonological awareness, including inviting children to read books, getting to know vocabulary through picture cards, imitating written forms and vocabulary, and other activities related to literacy. child. Literacy can be carried out well based on experience and knowledge and the availability of time used. A large amount of teacher knowledge about literacy will have an impact on the diversity of activities designed and useful for stimulating the development of children's language abilities from an early age. Thus the teacher's knowledge about literacy is needed so that the pros and cons of literacy issues for early childhood can be done with literacy activities according to children's age.
\end{abstract}

Keywords: Literasi; teacher perception; teacher practice; preschool

Copyright (c) 2020 Mutia Afnida, Suparno

$\triangle$ Corresponding author :

Email Address : mutiamafara@gmail.com (Aceh Singkil, Indonesia)

Received 25 February 2020, Accepted 12 March 2020, Published 14 March 2020

Jurnal Obsesi : Jurnal Pendidikan Anak Usia Dini, 4(2), 2020 | 971 


\section{PENDAHULUAN}

Literasi merupakan bagian dari perkembangan kemampuan bahasa anak yang sangat penting untuk distimulasi sejak usia usia dini. Sebelum anak dapat membaca dan menulis, melalui literasi dapat memberikan pengalaman pada anak tentang konsep pengetahuan huruf, kesadaran fonologi, pemahaman, kosakata, menulis dan membaca (Justice dan Sofka, 2013: 6; Rosemary dan Abouzeid, 2002: 182-183). Apabila anak memiliki pengalaman literasi maka anak akan dapat dengan mudah belajar membaca dan menulis, sehingga berdampak pada pencapaian akademik yang lebih baik (Dunphy, 2012: 297; Elliott dan Olliff, 2008: 555; Van Oers dan Duijkers, 2013: 512).

Kemampuan sebelum membaca dan menulis merupakan bagian dari aktivitas kognitif, seperti: kesadaran fonem, kosakata penulisan nama, dan indikator lainnya terkait kemampuan menceritakan kembali, pemahaman cerita dan sebagainya (Westerveld dkk., 2015: 348; Hill, 2010:323). Praktik literasi di PAUD berpengaruh pada kemampuan literasi awal anak usia dini (Dickinson dan Caswell, 2007: 255). Pendapat ini sejalan dengan hasil penelitian longitudinal Magnuson dkk., (2007: 33) bahwa praktik literasi memiliki efek jangka panjang yang dapat mempengaruhi perkembangan kemampuan bahasa anak.

Anak-anak yang menunjukkan kemampuan literasi yang baik sejak usia dini cenderung menjadi pembaca yang sukses (Chapman dan Prochnow, 2006; Shanahan dan Lonigan, 2013; Prioletta dan Pyle, 2017. Anak yang baru mulai masuk TK dengan keterlambatan kemampuan literasi kemungkinan selanjutnya akan terus terlambat dibanding dengan perkembangan anak seumurannya. Storch dan Whitehurst (2002) menjelaskan bahwa kesadaran fonologi bersamaan dengan pengetahuan tulisan, berdampak pada kemampuan belajar membaca anak di PAUD. Kesadaran fonologi yang diukur merupakan sebagai salah satu prediktor paling kuat dalam penguraian sandi, pemahaman membaca, dan keterampilan mengeja (Browne, 2001; P. M. Rhyner, 2009).

Prioletta dan Pyle (2017: 405-406) menjelaskan terkait praktik literasi untuk anak, dengan adanya ketersediaan sumber bacaan maupun tulisan di lingkungan bermain dapat diintegrasikan dengan permainan melalui kegiatan menulis, menggambar dan bermain drama sehingga dapat mendukung pengalaman literasi anak secara konkret. Hal ini sependapat dengan hasil penelitian Arsa (2019: 136) bahwa pengalaman literasi awal anak usia dini pada suku Anak Dalam terjadi melalui aktivitas menggambar, bercerita tentang pengalaman, berhitung, dan membaca. Selanjutnya Elliott dan Olliff (2008:552) menemukan bahwa pentingnya menciptakan kegiatan yang berkaitan dengan semua domain perkembangan anak (fisik, sosial-emosional dan kognitif) dengan cara yang menyenangkan dengan tujuan untuk memajukan pengembangan keterampilan literasi yang muncul dari anak-anak usia prasekolah.

Beberapa peneliti menyebutkan bentuk-bentuk program intervensi yang digunakan dalam mengembangkan kemampuan literasi anak, diantaranya: Justice dan Sofka (2013) mengembangkan konsep Read It Again-Prek! (RIA) yang bertujuan untuk memfasilitasi perkembangan kemampuan bahasa dan literasi anak usia dini dalam 4 bidang utama, yaitu: kosakata, cerita, kesadaran fonologi, dan pengetahuan tulisan; Vanderheyden dkk., (2008: 239) berkaitan dengan stimulus card untuk aliterasi dan rima; sedangkan (Yurick dkk., 2012: 89) mengembangkan program Early Reading Intervention (ERI) melalui penyerbuan kata dan identifikasi huruf-kata yang bertujuan untuk mengembangkan kemampuan anak dalam mengaplikasikan fonik dan kemampuan dalam menganalisis struktur pengucapan tulisan kata.

Hilbert dan Eis (2014: 108) mengkaji tentang program yang digunakan untuk mengembangkan kemampuan literasi anak dengan menggunakan konsep RIA, sehingga berdasarkan hasil yang diperoleh terdapat peningkatan yang signifikan terkait kosakata dan pengeahuan tulisan bagi anak. Melalui kesadaran fonologi memberikan pengetahuan yang berhubungan antara huruf dan bunyi huruf sehingga dapat menjadi landasan bagi anak dalam perkembangan membaca dan menulis (Scull dkk., 2012: 387). 
Pada tahun 2017, pemerintah Indonesia mencanangkan 'Gerakan Literasi Nasional (GLN)" melalui aktivitas literasi membaca (Alibaca) untuk penerapan literasi di lingkungan sekolah, keluarga dan masyarakat. Berdasarkan data yang diperoleh Alibaca masyarakat Indonesia termasuk dalam kategori 'aktivasi literasi rendah' dengan skor $M=37,32$. Provinsi Aceh juga berada pada kategori 'aktivasi literasi rendah' dengan nilai indeks 34,37 (Indeks Aktivitas Literasi Membaca 34 Provinsi, 2019).

Tidak terlepas dari program tersebut, pada tahun 2019 program kegiatan literasi dikembangkan dan difokuskan pada lingkungan keluarga dan dikenal dengan istilah Gerakan Nasional Orang Tua membacakan Buku (Gernas Baku). Hal ini bertujuan untuk meningkatkan partisipasi keluarga terutama orangtua dan lembaga PAUD agar dapat menumbuhkan budaya membaca kepada anak sejak usia dini (Panduan Pelaksanaan Gerakan Nasional Orang Tua Membacakan Buku (GERNAS BAKU), 2019). Seperti yang dijelaskan peneliti sebelumnya, budaya membaca melalui literasi yang dimulai sejak usia dini memiliki pengaruh yang besar untuk perkembangan kemampuan bahasa anak.

Literasi berkaitan dengan stimulasi perkembangan kemampuan bahasa anak dengan mengenal dan menceritakan bentuk tulisan/gambar yang terdapat didalam bacaan. Dengan adanya GLN dan Gernas Baku di lingkungan keluarga dan PAUD dapat memberikan pembiasaan pengenalan huruf dan kosakata, kesadaran fonem, dan pemahaman bacaan melalui tulisan/gambar. Maka dari itu, melalui penelitian ini kita dapat mengetahui sejauh mana guru dapat memahami dan menerapkan literasi di PAUD yang akan berdampak positif bagi perkembangan kemampuan bahasa anak.

\section{METODOLOGI}

Sampel dalam penelitian ini dipilih secara acak dari daftar lembaga pendidikan anak usia dini (PAUD) yang ada di wilayah Aceh. Terdapat 18 lembaga PAUD sebagai perwakilan dari beberapa wilayah Aceh yang setuju untuk berpartisipasi dalam penelitian ini. Penelitian ini melibatkan delapan belas guru PAUD yang mengajar di kelompok usia 3-6 tahun (jenis layanan kelompok berSyarahn dan taman kanak-kanak) yang berada di 6 wilayah Aceh (Banda Aceh, Aceh Besar, Aceh Jaya, Aceh Tengah, Aceh Selatan, dan Aceh Singkil).

Rata-rata delapan belas guru ini memiliki pengalaman mengajar selama 5 hingga 19 tahun. Satu orang guru berlatar belakang pendidikan sekolah menengah atas (SMA), satu orang guru berlatar belakang sarjana pendidikan, dua guru berlatar belakang diploma dan empat belas guru berlatar belakang sarjana pendidikan anak usia dini. Dari delapan belas partisipan, kemudian dipilih secara acak empat guru yang memiliki 3 kriteria (guru kelas, berlatar belakang sarjana PAUD, dan minimal 5 tahun berpengalaman mengajar di PAUD) untuk diwawancarai lebih lanjut terkait praktik guru pada kegiatan literasi dalam pembelajaran di PAUD.

Data diperoleh melalui wawancara dan kuisioner. Data wawancara dianalisis melalui tahapan reduksi data, sajian data dan penarikan kesimpulan. Sedangkan data kuantitatif yang diperoleh melalui kuisioner menggunakan analisis statistik deskriptif. Wawancara terdiri dari 9 item pertanyaan yang didasarkan pada penelitian sebelumnya (Scull dkk., 2012). Tujuan dilakukannya wawancara adalah untuk mengetahui bagaimana peranan guru dalam menstimulasi perkembangan literasi awal anak.

Selanjutnya kuisioner disebar melalui survei online yang terdiri dari 73 item pertanyaan dengan tujuan untuk mengetahui bagaimana guru memahami tentang literasi dan penerapannya di dalam praktik pembelajaran di kelas. Seluruh pertanyaan tergabung dalam 5 bagian sub pertanyaan. Setiap item pertanyaan diadobsi berdasarkan penelitian terdahulu yang berkaitan dengan tanggapan dan pengetahuan guru terkait literasi (Scull dkk., 2012) dan praktik literasi di lingkungan PAUD (Matsumoto dan Tsuneda, 2019; Sandvik dkk., 2014). Selanjutnya, reliabilitas dari keseluruhan pertanyaan memperoleh skor $0,795(\lambda>0,444)$ sedangkan tiap item sub bagian pernyataan disajikan pada Tabel 1. 
Bagian 1 (latar belakang guru) memuat pertanyaan mengenai jenis layanan PAUD, jenis kelamin, latar belakang pendidikan, pengalaman pelatihan, posisi, dan pengalaman mengajar. Bagian 2 (pengetahuan dan praktik guru) menanyakan tentang pengetahuan dan praktik guru di PAUD mengenai cara anak belajar dan literasi pada anak usia dini. Bagian 3 (persepsi) terdiri dari 12 pernyataan yang dirancang untuk menunjukkan persepsi guru tentang peranannya pada kegiatan literasi di PAUD. Dalam hal ini partisipan diminta untuk memilih diantara enam pernyataan dari 1 (sangat tidak setuju) sampai 4 (sangat setuju).

Tabel 1. Reliabilitas Skala Persepsi dan Praktik Guru (N=18)

\begin{tabular}{|l|l|c|}
\hline \multicolumn{1}{|c|}{ Section } & \multicolumn{1}{|c|}{ Scale (number of items) } & Cronbach's $\boldsymbol{\alpha}$ \\
\hline Persepsi & Peranan guru di TK (12) &, 766 \\
\hline Praktik & Kualitas penggunaan buku (12) &, 747 \\
\hline Praktik & Kesadaran fonologi(5) &, 755 \\
\hline Praktik & Pengetahuan huruf (5) &, 766 \\
\hline Waktu & Kuantitas aktivitas literasi (10) &, 745 \\
\hline
\end{tabular}

Bagian 4 (praktik) terdiri dari 25 pernyataan yang dirancang untuk menentukan praktik guru dalam stimulasi literasi dalam pembelajaran, diantaranya: a) kualitas penggunaan buku, b) kesadaran fonologi, dan c) pengetahuan huruf. Empat point dari skala Likert digunakan untuk menentukan frekuensi dari 1 (tidak pernah) hingga 4 (selalu). Bagian 5 (waktu) terdiri dari 10 pernyataan yang dimaksudkan untuk mengetahui durasi waktu yang digunakan guru pada kegiatan literasi setiap harinya. Skala frekuensi menggunakan durasi menit per hari yaitu 1 (0 menit) hingga 5 (20 menit atau lebih).

Desain penelitian dapat dilihat pada gambar 1

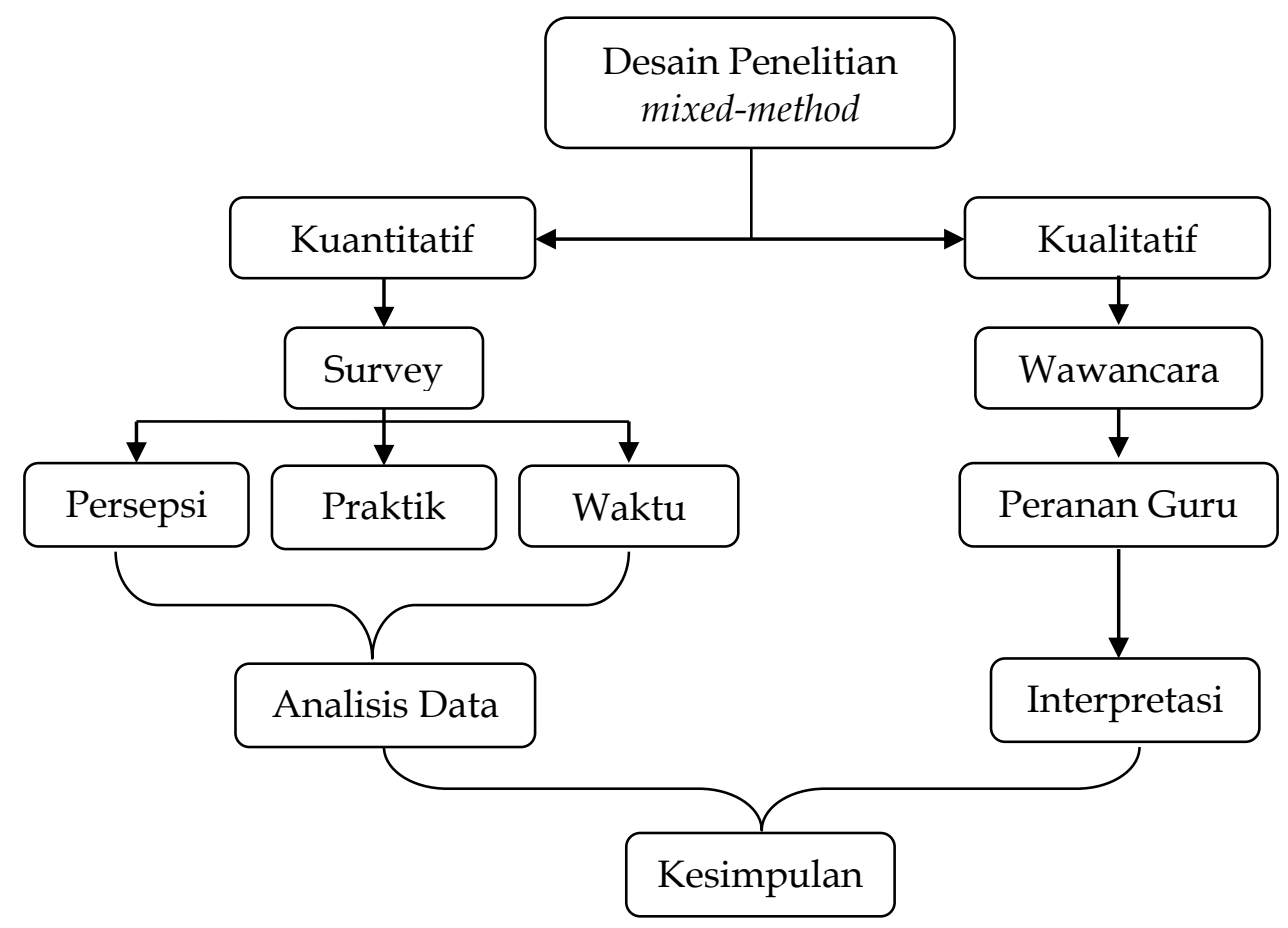

Gambar 1 Desain Penelitian

\section{HASIL DAN PEMBAHASAN}

Hasil yang dijabarkan berdasarkan 18 guru menggambarkan eksplorasi pemahaman guru-guru PAUD tentang literasi yang berfokus pada praktik di kelas. Termasuk dalam hal ini empat hasil wawancara studi kasus yang mewakili berbagai pandangan guru berkaitan dengan kegiatan literasi dalam konteks PAUD dan bagaimana pandangan tersebut 
dipraktikkan dalam kegiatan pembelajaran. Dapat dikatakan bahwa keempat hasil wawancara ini dapat mewakili perbedaan pandangan dari 18 guru yang ikut serta dalam penelitian ini.

Dari 18 guru, 72,2\% guru berlatar belakang sarjana pendidikan anak usia dini dan telah mengikuti berbagai macam pelatihan yang berkaitan dengan pendidikan anak, diantaranya: pelatihan kurikulum, pelatihan peningkatan kompetensi pembelajaran, pendidikan dan pelatihan dasar (Diklat Dasar), dan pelatihan bercerita. Selain itu, beberapa guru juga pernah mengikuti pelatihan berkaitan dengan bahasa dan literasi anak yaitu pelatihan mendongeng dan pelatihan penggunaan buku 9 pilar karakter karya Ratna Megawangi.

Dalam buku 9 pilar karakter mengajak guru untuk menceritakan sebuah cerita berdasarkan gambar yang terdapat pada bab nilai-nilai karakter yang diperkenalkan setiap harinya. Selain mengenalkan nilai-nilai karakter melalui cerita, anak juga diajak untuk melakukan aktivitas literasi yang mana guru berperan aktif menceritakan isi buku, namun kadang kala guru memberikan kesempatan kepada anak untuk mencoba menafsirkan atau menceritakan isi cerita sesuai dengan gambar yang ada di dalam buku 9 pilar karakter tersebut.

Berdasarkan data yang diperoleh, mayoritas guru mengetahui informasi terkait literasi melalui program pemerintah 'Gernas Baku' (Gerakan Nasional Orangtua Membacakan Buku) yang ditujukan pada lembaga PAUD agar melibatkan orangtua dalam pembiasaan membacakan buku untuk anak. Sehingga melalui program tersebut sekolah membuat pojok baca di setiap sudut ruang kelas dan setiap jurnal pagi (sebelum kegiatan pembelajaran dimulai) orangtua diminta untuk membacakan buku cerita pada anak selama \pm 5 menit.

Ketika diminta untuk mendefinisikan literasi, tanggapan guru-guru mencakup istilah literasi secara umum yang mengindikasikan konseptualisasi perspektif mereka terkait fungsi dan tujuan literasi. Secara eksplisit guru menyebutkan literasi sebagai kemampuan yang berkaitan dengan membaca, menulis, memahami dan mengolah informasi. Guru menyadari beberapa faktor yang mempengaruhi perkembagan literasi anak yaitu: kebiasaan orangtua membacakan buku pada anak, kesempatan interaksi tanya-jawab, dan ketersediaan buku di sekitar anak.

Dalam membantu perkembangan literasi anak, guru meluangkan waktu membacakan buku pada anak salah satunya yang berkenaan dengan karakter. Selain itu, guru mengenalkan kosakata menggunakan kartu bergambar, dan beragam jenis permainan mencocokkan dan menyusun kata. Selanjutnya dalam memberikan pengalaman baca-tulis, guru mengajak anak untuk menyebutkan nama-nama hari beserta tanggal sembari guru menuliskannya di papan tulis dan kadang guru memberi kesempatan anak untuk menyebutkan dan menuliskannya di papan tulis.

Pada anak kelompok usia 3-4 tahun guru tidak memfokuskan pada kemampuan baca-tulis, namun lebih kepada pengenalan kosakata menggunakan kartu kosakata berga mbar Berbeda dengan kelompok usia 4-6 tahun, guru sudah memulai untuk fokus pada kemampuan baca-tulis anak. Selain itu, salah satu cara guru dalam menstimulasi kemampuan literasi dan kemampuan membaca anak yaitu menggunakan kartu kreatif huruf yang telah dirancang sekolah untuk membantu orangtua dalam mengenalkan huruf pada anak di rumah.

\section{Studi Kasus Satu - Suri}

Suri telah bekerja di PAUD selama 6 tahun, dan memiliki kualifikasi sarjana pendidikan anak usa dini. Dalam mendefinisikan literasi, Suri menyatakan bahwa: 
Saya memahami 'literasi' sebagai suatu kemampuan yang berkaitan dengan membaca dan menulis dan melihat sebagai praktik yang mencerminkan bagaimana anak dapat mengenal huruf dan kosa kata secara langsung.

Uraian penjelasan lebih lanjut:

Pada saat mengenalkan kosakata baru pada anak, contohnya 'Bola', saya memperjelas pengucapan kata BOLA satu persatu yang kemudian saya tuliskan di papan tulis. Kadangkadang saya meminta anak untuk menebak kata selanjutnya melalui pelafalan kata yang saya ucapkan.

Pada dasarnya aktivitas pembelajaran yang dilakukan oleh Suri terkait pengembangan literasi lebih difokuskan pada kemampuan membaca dan menulis. Setiap harinya dikegiatan awal pembelajaran anak diperkenalkan kosakata baru, sedangkan diakhir pembelajaran meminta anak untuk mengingat dan menyebutkan kosakata apa saja yang telah dipelajari pada hari tersebut. Kegiatan lainnya terkait literasi dilakukan menggunakan puzzle huruf bergambar, anak diminta untuk mencocokkan kata dan gambar, selanjutnya Suri mengajak anak untuk mengulang susunan kata tersebut. Selain itu aktivitas literasi dilakukan melalui kegiatan mengenal bentuk susunan nama dan meminta anak menirukan tulisan dari nama anak tersebut sesuai dengan contoh yang diberikan.

Saya mengajak anak untuk terbiasa mengetahui bentuk kata dari nama anak sendiri dengan menggunakan tempelan nama yang ada di keranjang alat tulis pribadi anak. Selanjutnya saya meminta anak untuk terbiasa menulis sendiri namanya sesuai dengan susunan kata yang terdapat pada keranjang pribadi anak. Apabila anak lupa susunan huruf dari namanya tersebut, anak dapat melihat kembali namanya yang telah tertera di keranjang alat tulis miliknya.

Literasi dikonsepkan guru sebagai kemampuan yang dibutuhkan anak untuk dapat mengoperasikan sistem bahasa yang kemudian digunakan untuk tujuan pembuatan makna sendiri (Durrant dan Green, 2000).

\section{Studi Kasus Dua - Fitri}

Pengalaman mengajar Fitri di lembaga PAUD telah dilaluinya selama 5 tahun, dan ia juga telah menamatkan pendidikan sarjana di bidang pendidikan anak usia dini. Terkait definisi literasi, Fitri menyatakan bahwa 'literasi merupakan kemampuan keaksaraan'.

Saya mengajak anak mengenal huruf menggunakan alat pembelajaran edukatif (APE). Kebetulan saya mengajar anak kelompok usia 4-5 tahun, dan tidak menekankan pembelajaran baca-tulis. Kegiatan yang berhubungan dengan literasi dilakukan dengan alat permainan yang tersedia. Adapun buku-buku yang tersedia juga jarang digunakan, karena fasilitas buku yang sedikit sehingga penempatan akses buku yang tidak dekat dengan anak.

Pada studi kasus dua ini, aktivitas literasi dilakukan dengan pengenalan huruf dan kosakata nama-nama benda menggunakan majalah. Selain itu guru memberikan contoh kata 'ayam' yang dituliskan di buku kotak-kotak, kemudian meminta anak untuk menirukan kata tersebut. Kegiatan lainnya terkait keaksaraan diantaranya: menebalkan huruf, menarik garis yang memiliki pola bentuk huruf.

\section{Studi Kasus Tiga - Sari}

Sari telah berpengalaman mengajar selama 7 tahun dikelompok usia 5-6 tahun dan berlatar belakang sarjana pendidikan anak usia dini. Dalam mendefinisikan istilah literasi, Sari menyatakan: 
DOI: $10.31004 /$ obsesi.v4i2.480

Literasi dipahami berkaitan dengan mengenal kosakata dan membaca seperti memberikan kesempatan anak membaca dan dibacakan buku cerita yang anak sukai. Contoh lebih jelasnya, ketika saya bercerita kemudian memberikan kesempatan pada anak untuk bertanya dan menjawab pertanyaan. Selain itu, menggunakan kartu karakter pada kegiatan mengenalkan huruf dan menyusun kata.

Sari mencoba mendefinisikan literasi sebagai kemampuan yang berkaitan dengan mengenal huruf dan membaca. Pada kegiatan membaca, dalam situasi yang dialami oleh Sari, anak bercerita lebih terfokus pada kata-kata yang terdapat di buku. Aktivitas yang biasa dilakukan Sari dalam menstimulasi literasi anak yaitu menggunakan kartu huruf karakter. Adapun pembahasan tentang ini sebagai berikut:

Saya setiap harinya selama 30 menit mengajak anak untuk mengenal huruf menggunakan kartu huruf kreatif yang dirancang sendiri oleh sekolah untuk membantu anak membaca terutama mengenalkan kosakata. Saya mengenalkan satu karakter setiap harinya dan mengenalkan kosakata yang tertera pada karakter tersebut, setelah itu saya meminta anak untuk menggabungkan huruf per huruf sehingga membentuk seperti kata yang sesuai dengan kartu huruf karakter tersebut.

Semua guru mampu menyebutkan kegiatan-kegiatan literasi yang mereka lakukan, sehingga perlu adanya kesadaran guru PAUD terkait pentingnya pembelajaran literasi serta komitmen dan konsistensi dalam pelaksanaan pembelajaran yang disesuaikan dengan perkembangan dan pemahaman terbaru mengenai literasi awal sebelum anak memasuki usia sekolah (Scull dkk., 2012). Dapat disimpulkan bahwa, guru memainkan peranan penting dalam memberikan kesempatan bagi anak usia dini untuk bereksperimen dan bereksplorasi pada pembelajaran literasi yang merupakan dasar awal pembelajaran anak selanjutnya.

\section{Studi Kasus Empat - Syarah}

Syarah telah berpengalaman mengajar anak usia dini selama 8 tahun dan memiliki kualifikasi sarjana pendidikan anak usia dini. Dalam mendefinisikan literasi, Syarah menyatakan:

Mengajak anak mengenal buku, membaca buku dan mencintai buku dengan tujuan untuk meningkatkan minat baca anak

Uraian lanjutan sebagai berikut:

Mengajak anak untuk mengenal, membaca dan mencintai buku tidak hanya diterapkan disekolah. Namun dari pihak sekolah juga menerapkan program home visit yang dilakukan sebulan sekali dan bertujuan untuk mengetahui ketersediaan buku untuk anak di rumah dan kesempatan waktu yang diberikan orangtua untuk terlibat membacakan buku pada anak. Selain itu, di setiap kelas juga tersedia pojok baca. Kegiatan yang dilakukan di pojok baca tidak mengikuti jadwal pembelajaran yang telah ditentukan, akan tetapi anak dapat melakukan aktivitas membaca buku di pojok baca pada saat menunggu jemputan.

Syarah menekankan literasi berbasis buku cerita dalam definisi mengeksplorasi kesenangan yang dimiliki anak terhadap buku dalam aktivitas literasi. Studi kasus ke-empat ini mengungkapkan keterpaduan yang erat antara pandangan guru tentang literasi dan kegiatan yang dilakukan. Syarah memiliih kegiatan mengenal huruf, anak diminta untuk menempelkan susunan huruf berdasarkan contoh yang ada dan meminta anak menyebutkan huruf tersebut. Pembahasan tentang kegiatan ini sebagai berikut: 
Kegiatan keaksaraan tidak hanya mengajak anak untuk mengenal huruf. Contohnya, anak dapat mengena bentuk huruf dan memfungsikan indra perabanya melalui tekstur tempelan papan huruf. Saya merancang bentuk huruf menggunakan kain flanel dan papan tempelan huruf menggunakan kertas amplas kayu. Kegiatan lainnya saya juga menggunakan kartu huruf bergambar yang didesain timbal balik (Gambar apel, dibalik gambar ada huruf A). Kegiatan literasi lainnya yang saya lakukan adalah dengan memberikan pensil dan kertas kosong pada anak-anak dan memberikan kebebasan pada mereka untuk berkreasi dan berimajinasi, setelah anak-anak selesai guru meminta anak untuk menceritakan apa yang telah digambar oleh anak.

Literasi dalam hal ini dilakukan dalam konteks autentik dan tujuan pembelajaran menggunakan praktik dan bermakna (Durrant dan Green, 2000). Literasi dipandang lebih dari sekedar memiliki kemampuan dalam mengoperasikan sistem bahasa, sebaliknya literasi mampu membuat anak melakukan sesuatu yang berkaitan dengan dunia mereka sehingga dapat mencapai suatu tujuan yang ingin dicapai.

\section{Statistik Deskriptif Persepsi dan Praktik Literasi Guru PAUD Persepsi}

Tabel 2. Skala Mean dan Standar Deviasi persepsi guru di tujuh kabupaten Aceh $(\mathrm{N}=18)$

\begin{tabular}{ccc}
\hline Scale Areas & Mean & SD \\
\hline Banda Aceh & 44,50 & 3,873 \\
Aceh Besar & 38,33 & 4,726 \\
Aceh Jaya & 43,33 & 4,509 \\
Aceh Tengah & 42,67 & 6,807 \\
Aceh Selatan & 38,50 & 2,121 \\
Aceh Singkil & 44,33 & 4,726 \\
\hline
\end{tabular}

Tabel 2 menggambarkan tanggapan positif guru mengenai literasi pada pendidikan anak usia dini. Mayoritas berdasarkan hasil persepsi guru menjawab bahwa mereka 'sangat setuju' atau 'setuju' pada tiap item pernyataan yang menunjukkan peranan guru dalam menstimulasi perkembangan literasi anak sejak usia dini.

\section{Praktik}

Tabel 3 menunjukkan skor mean dan standard deviasi dari respon guru pada bagian item pertanyaan praktik guru. Secara keseluruhan mayoritas guru menjawab 'selalu' (52,9\%) yang menandakan persentase dari frekuensi guru dalam memberikan praktik literasi di kelas.

Tabel 3. Skala Mean dan Standar Deviasi Praktik Guru (N=18)

\begin{tabular}{lcc}
\hline \multicolumn{1}{c}{ Category } & Mean & SD \\
\hline Peranan guru PAUD & 42,28 & 4,750 \\
Kualitas penggunaan buku & 50,06 & 6,708 \\
Kesadaran fonologi & 16,44 & 4,462 \\
Pengetahuan huruf & 15,00 & 4,173 \\
Jumlah waktu pada aktivitas literasi & 27,17 & 6,382 \\
\hline
\end{tabular}

\section{Kuantitas Waktu}

Mayoritas guru $(35,6 \%)$ menghabiskan waktu $\pm 5-10$ menit per hari dalam satu kegiatan yang berkaitan dengan literasi. Hanya 9,6\% guru yang melaporkan kegiatan literasi dilakukan lebih dari 20 menit.

Berdasarkan data skala praktik yang dilakukan guru yang berkaitan dengan literasi, dapat kita lihat bahwa adanya dukungan positif guru terkait pengembangan kemampuan literasi yang tergambarkan pada praktik pengajaran yaitu kualitas guru menggunakan buku, 
praktik kesadaran fonologi dan praktik pengetahuan huruf. Selanjutnya rata-rata waktu yang dihabiskan guru terkait literasi hanya dalam rentang waktu 5-10 menit. Ada praktik yang dilakukan guru secara intens selama rentang waktu tersebut, namun ada juga dilakukan selingan beberapa menit dan dilanjutkan beberapa menit di waktu yang berbeda.

Selanjutnya berdasarkan hasil yang diperoleh, guru-guru memiliki penafsiran pandangan dan praktik yang berbeda terkait literasi, seperti mengajak anak membaca buku, mengenal kosakata melalui kartu bergambar, menirukan nama dan tulisan kosakata lainnya, dan kegiatan lainnya yang berhubungan dengan baca-tulis anak. Neuman dan Dickinson (2003) memaparkan contoh perilaku yang berkaitan dengan literasi yaitu: pura-pura membaca buku, mengubah bunyi-bunyi dalam satu kata, mengamati tulisan yang ada di buku, label ataupun tulisan iklan yang ada di sekitar lingkungan anak sebagai aspek penting dalam proses perkembangan literasi anak. Sehingga dapat kita simpulkan bahwa, aktivitas perilaku yang mengarah pada kemampuan membaca dan menulis dianggap sebagai kegiatan yang bertujuan untuk mengarahkan anak pada pembentukan perilaku membaca dan menulis yang konvensional.

Literasi terbagi dalam dua domain yaitu inside-out dan outside-in (Britto dkk., 2006). Seperti praktik yang pada umumnya dilakukan guru dalam mengenalkan kosakata pada anak dengan cara menyebutkan kata dengan pelan dan jelas, kemudian menuliskan setiap item huruf di papan tulis. Sama halnya dengan makna inside-out yaitu pengetahuan mengenai aturan-aturan mentransformasikan tulisan ke bentuk suara dan suara ke bentuk tulisan (Neuman dan Dickinson, 2003). Sedangkan outside-in adalah informasi yang berasal dari luar tulisan yang mengarahkan pemahaman seseorang akan makna tulisan, seperti: skema cerita pengetahuan konseptual, dan kosakata. Hal ini juga berkaitan dengan praktik literasi yang guru lakukan menggunakan kartu huruf bergambar atau kartu kreatif karakter. Anak memahami bahwa tulisan memiliki makna yang berhubungan dengan gambar. Contohnya: tulisan kata 'Apel' dan dibalik tulisan terdapat gambar apel. Sehingga melalui aktivitas ini merupakan salah satu cara anak memahami makna tulisan dalam pemerolehan kosakata baru bagi anak.

Pandangan literasi guru terkait literasi yaitu pertama, guru mengakui pentingnya literasi untuk anak sejak usia dini. Semua guru mampu melihat peluang pembelajaran literasi melalui kegiatan-kegiatan yang mereka lakukan, sehingga perlunya tingkat kesadaran yang tinggi dan perilaku konsisten guru terhadap pengembangan pembelajaran literasi. Karena guru memainkan peranan penting dalam memberikan kesempatan bagi anak untuk bereksplorasi dengan kegiatan literasi yang merupakan bekal anak untuk perkembangan selanjutnya (Matsumoto dan Tsuneda, 2019: 12).

Kedua, pengalaman belajar yang dipilih guru merupakan pengaruh dari pengetahuan yang diperoleh guru. Beberapa guru mendasari kegiatan literasi yang berkaitan dengan membaca buku, menulis atau menirukan kata. Namun tanpa disadari, literasi tertanam dalam kegiatan permainan anak sehari-hari. Ketiga, hasil penelitian ini menunjukkan bahwa kegiatan literasi yang dipilih mencerminkan bagaimana guru mengkonseptualisasikan pengajaran dan pembelajaran literasi berkaitan dengan kebutuhan anak.

Analisis terkait pemahaman dan praktik guru terhadap literasi sering menunjukkan preferensi pada orientasi kognitif dan sosial. Contohnya: belajar huruf yang dilakukan oleh anak-anak mengembangkan kesadaran fonologis dalam konteks pelafalan bunyi huruf, sedangkan orientasi sosial berkaitan dengan penekanan pada interaksi dan komunikasi yang bermakna sebagaimana terbukti dalam kegiatan membaca buku. Tidak peduli bagaimana literasi diposisikan, bagian yang terpenting bahwa kegiatan literasi yang dilakukan dengan cara yang menyenangkan sehingga memiliki kebermaknaan dalam menyediakan landasan yang kokoh untuk pengajaran dan pembelajaran literasi sejak dini. 


\section{SIMPULAN}

Pendidik perlu mengetahui dan mengidentifikasi terkait perkembangan literasi bagi anak usia dini. Perlunya pelatihan dan pengarahan khusus terkait pengetahuan pengembangan literasi bagi guru, sehingga guru tidak memiliki keraguan terhadap pengembangan kegiatan yang dilakukan yang berkaitan dengan literasi dan kemampuan bahasa anak. Sementara pada penelitian ini terbatas pada 18 guru PAUD yang tidak berfokus pada dampak praktik yang dilakukan guru-guru PAUD terhadap pengalaman anak dalam pembelajaran literasi atau melek huruf, namun yang ditemukan dalam penelitian ini bahwa guru-guru yang terlibat telah menanamkan konsep literasi dalam praktik mengajar mereka dengan beragam cara yang dilakukan oleh guru. Guru-guru ini menyadari akan peranan mereka dalam memfasilitasi perkembangan literasi anak sejak dini dan menerapkan konsep literasi sesuai dengan pengetahuan dan pemahaman masingmasing guru terkait pengembangan literasi.

\section{UCAPAN TERIMAKASIH}

Terimakasih penulis sampaikan kepada Lembaga Pengelola Dana Pendidikan (LPDP) sebagai lembaga yang telah memberikan bantuan materil, sehingga peneliti dapat melakukan dan menyelesaikan penelitian ini.

\section{DAFTAR PUSTAKA}

Arsa, D. (2019). Literasi Awal pada Anak Usia Dini Suku Anak Dalam Dharmasraya. Jurnal Obsesi: Jurnal Pendidikan Anak Usia Dini, 3(1), 127-136. https:// doi.org/10.31004/obsesi.v3i1.159.

Britto, P. R., Fuligni, A. S., \& Brooks-Gunn, J. E. A. N. N. E. (2006). (2006). Reading ahead: Effective interventions for young children's early literacy development. In Handbook of early literacy research (Volume 2, pp. 311-332).

Browne, A. (2001). Developing Language and Literacy 3-8 (2nd ed.). SAGE Publication Company.

Chapman, J., \& Prochnow, J. (2006). Literate cultural capital at school entry predicts later reading achievement: A seven year longitudinal study. New Zealand Journal of Educational Studies, 41(2), 183-204.

Dickinson, D. K., \& Caswell, L. (2007). Building support for language and early literacy in preschool classrooms through in-service professional development: Effects of the Literacy Environment Enrichment Program ( LEEP ). Early Childhood Research Quar, 22, 243-260. https:// doi.org/10.1016/j.ecresq.2007.03.001.

Dunphy, E. (2012). Children's participation rights in early childhood education and care: The case of early literacy learning and pedagogy. International Journal of Early Years Education, 20(3), 290-299. https://doi.org/10.1080/09669760.2012.716700.

Durrant, C., \& Green, B. (2000). Literacy and the New Technologies in sSchool Education: Meeting the L(IT)eracy Challenge? Australian Journal of Language and Literacy, 23(2).

Elliott, E. M., \& Olliff, C. B. (2008). Developmentally appropriate emergent literacy activities for young children: Adapting the early literacy and learning model. Early Childhood Education Journal, 35(6), 551-556. https:// doi.org/10.1007/s10643-007-0232-1

Hilbert, D. D., \& Eis, S. D. (2014). Early Intervention for Emergent Literacy Development in a Collaborative Community Pre-Kindergarten. Early Childhood Education Journal, 42(2), 105-113. https:// doi.org/10.1007/s10643-013-0588-3

Hill, S. (2010). The millennium generation: Teacher-researchers exploring new forms of literacy. Journal of Early Childhood Literacy, 10(3), 314-340. https:/ / doi.org/10.1177/1468798410372820

Indeks Aktivitas Literasi Membaca 34 Provinsi. (2019) (pertama). Puslitjakdikbud.

Justice, L. M., \& Sofka, A. E. (2013). Engaging children with print: Building early literacy skills through quality read-alouds. New York: Guilford Publications. 
Magnuson, K. A., Ruhm, C., \& Waldfogel, J. (2007). The persistence of preschool effects : Do subsequent classroom experiences matter? Early Childhood Research Quarterly, 22, 18 38. https:// doi.org/10.1016/j.ecresq.2006.10.002

Matsumoto, H., \& Tsuneda, M. M. (2019). Teachers' beliefs about literacy practices for young children in early childhood education and care settings. International Journal of Early Years Education, 27(4), 441-456. https:/ / doi.org/10.1080/09669760.2018.1547630

Neuman, S. B., \& Dickinson, D. K. (2003). Emergent literacy: Development from prereaders to readers. In Handbook of early literacy research, Volume 1 (pp. 11-29).

Panduan Pelaksanaan Gerakan Nasional Orang Tua Membacakan Buku (GERNAS BAKU). (2019). Kementerian Pendidikan dan Kebudayaan.

Prioletta, J., \& Pyle, A. (2017). Play and gender in Ontario kindergarten classrooms: implications for literacy learning. International Journal of Early Years Education, 25(4), 393-408. https://doi.org/10.1080/09669760.2017.1390446

Rhyner, P. M. (2009). Emergent Literacy and Language Development: Promoting Learning in Early Childhood. (P. M. Rhyner, Ed.). Guilford Press.

Rosemary, C. A., \& Abouzeid, M. P. (2002). Developing literacy concepts in young children: An instructional framework to guide early literacy teaching. Journal of Early Childhood Teacher Education, 23(2), 181-201. https:/ / doi.org/10.1080/1090102020230210

Sandvik, J. M., van Daal, V. H. P., \& Adèr, H. J. (2014). Emergent literacy: Preschool teachers' beliefs and practices. Journal of Early Childhood Literacy, 14(1), 28-52. https://doi.org/10.1177/1468798413478026

Scull, J., Nolan, A., \& Raban, B. (2012). Young learners: Teachers' conceptualisation and practice of literacy in Australian preschool contexts. International Journal of Early Years Education, 20(4), 379-391. https:/ / doi.org/10.1080/09669760.2012.743101

Shanahan, T., \& Lonigan, C. J. (2013). Early childhood literacy: The national early literacy panel and beyond. Paul $\mathrm{H}$. Brookes Publishing Company.

Storch, S. A., \& Whitehurst, G. J. (2002). Oral Language and Code-Related Precursors to Reading: Evidence From a Longitudinal Structural Model. Developmental Psychology, 38(6), 934-947. https:// doi.org/10.1037//0012-1649.38.6.934

Van Oers, B., \& Duijkers, D. (2013). Teaching in a play-based curriculum: Theory, practice and evidence of developmental education for young children. Journal of Curriculum Studies, 45(4), 511-534. https:/ / doi.org/10.1080/00220272.2011.637182

Vanderheyden, A. M., Snyder, P. A., Broussard, C., \& Ramsdell, K. (2008). Measuring Response to Early Literacy Intervention With Preschoolers at Risk. Topics in Early Childhood Special Education, 27(4), 232-249.

Westerveld, M. F., Gillon, G. T., van Bysterveldt, A. K., \& Boyd, L. (2015). The emergent literacy skills of four-year-old children receiving free kindergarten early childhood education in New Zealand. International Journal of Early Years Education, 23(4), 339351. https:// doi.org/10.1080/09669760.2015.1033617.

Yurick, A., Cartledge, G., Kourea, L., \& Keyes, S. (2012). Reducing Reading Failure for Kindergarten Urban Students: A Study of Early Literacy Instruction, Treatment Quality, and Treatment Duration. Remedial and Special Education, 33(2), 89-102. https://doi.org/10.1177/0741932510365359. 